\title{
Role of Seed-Fe Content on Seed Longevity of Pigeonpea Genotypes
}

\author{
D. Hanumanthappa ${ }^{1}$, S. N. Vasudevan ${ }^{2}$, N. M. Shakuntala ${ }^{3}$, \\ N. M. Muniswamy ${ }^{4}$, Sangeetha I. Maacha ${ }^{5}$ and Umesh Hiremath ${ }^{6}$ \\ ${ }^{1}$ Agricultural Research Station, Siruguppa, ${ }^{2}$ VC Farm Mandya, ${ }^{3}$ Department of SST, \\ ${ }^{4}$ Department of GPB AC Kalaburagi, ${ }^{5}$ Department of SST, UAS, Raichur, ${ }^{6}$ Seed Unit, UAS \\ Raichur, UAS, Raichur-584 104, Karnataka, India \\ *Corresponding author
}

\section{A B S T R A C T}

\section{Keywords}

Seed, Iron, Zinc, Pigeonpea, Seed longevity

\section{Article Info}

Accepted:

22 March 2020

Available Online:

10 April 2020
Fifteen pigeonpea genotypes were studied to establish the role of seed-Fe content in maintaining seed longevity of pigeonpea genotypes and the results revealed the clear genotypic variability with respect to storability among different pigeonpea genotypes. The genotype with highest seed-Fe content $(85.01 \mathrm{ppm})$ proved as good storer by recording highest seed quality parameters viz., seed germination $(84.57 \%)$, seedling length (27.67 $\mathrm{cm})$, seedling vigour index (1303), seedling dry weight $(80.67 \mathrm{mg}$ g), speed of germination (23.29\%), dehydrogenase enzyme activity (0.551 OD value), $\alpha$-amylase activity $(28.46 \mathrm{~mm})$ with lowest electrical conductivity $(1.04 \mu \mathrm{S} / \mathrm{cm})$ and moisture content $(7.29 \%)$ at the end of twelve months of storage period. Whereas, genotypes with low seed-Fe content exhibited lowest seed quality parameters.

\section{Introduction}

Pigeonpea [Cajanus cajan (L.) Millsp] is an important grain legume that has primarily originated in the Indian sub-continent. It has a wide range of maturity which helps in its adaption in a wide range of environments and cropping systems. It is a major source of protein for several resource poor rural and urban families of Asia, Africa. Being a pulse crop, pigeonpea enriches soil through symbiotic nitrogen fixation, releases soil- bound phosphorous, recycles the soil nutrients, adds organic matter and other nutrients that make pigeonpea an ideal crop for sustainable agriculture (Saxena, 2008). Its dry crushed seeds have high protein content (20-25\%) which acts as major source of protein for vegetarian people.

More than 85 per cent of the world's pigeonpea is produced and consumed in India. It is commonly known as redgram or arhar or tur or thogari. The world acreage of 
pigeonpea is $4.86 \mathrm{~m}$ ha with an annual production of $4.1 \mathrm{mt}$ and productivity of 900 $\mathrm{kg} / \mathrm{ha} \quad$ across $\quad 50 \quad$ countries (http://www.faostat.fao.org).

India is the largest producer and consumer of pigeonpea with an annual production of 3.29 $\mathrm{mt}$ in an area of $3.88 \mathrm{~m}$ ha with a productivity of $849 \mathrm{~kg}$ per ha, followed by Myanmar $(0.60$ $\mathrm{mt})$, Malawi $(0.16 \mathrm{mt})$ and Kenya $(0.10 \mathrm{mt})$. In India, it is one of the very important grain legumes and mainly grown in the states of Maharashtra, Karnataka, Madhya Pradesh, Uttar Pradesh and Gujarat. In Karnataka it is grown in an area of about $0.82 \mathrm{~m}$ ha with a production of $0.60 \mathrm{mt}$. Average productivity of pigeonpea in Karnataka accounts for 700 $\mathrm{kg}$ per ha and its potential yield marked up to 3.5 tonnes per ha. Its area, production and productivity in India in last five decades showed that there was about two per cent area increase per year but the yield levels were stagnated around 600-700 kg per ha (Anon., 2014).

High quality seeds play key role to successful agriculture. Modern agriculture with its bias for technology and precision, demands each and every seed should readily germinate and produce vigorous seedling ensuring high yield. Besides, uniformity of growth and synchrony in development are highly desirable characters. Maintenance of seed vigour and viability during storage is a matter of prime concern in India. Owing to the prevailing subtropical climate in the major parts of the country, seeds of most crop species show rapid deterioration. In general, there are differences among the species and also among the varieties within a species with respect to loss of viability during storage of pigeonpea. Hence, there is a need to identify the genotypes with good seed longevity for use in crop improvement programme. This is because crop vigour can change with increases in iron, zinc or phytate content, which are all related to seedling vigour and establishment. Efficient plant nutrient scavenging and uptake mechanisms are useful agronomically for the enhancement of crop health. Keeping this in view, the present study was undertaken to screen the available genotypes of pigeonpea and select the better storer entries with good viability.

The acquisition of metal ions, such as Fe, is important for plant survival. Iron has special importance because its ability to change redox states, making it an indispensable cofactor that is responsible for the function of electron transporter chains and catalytic processes (Briat, 2011). However, Fe over accumulation may lead to the overproduction of reactive oxygen species, resulting in cellular damage, necrosis, and, potentially, death. Therefore, the amount of Fe taken up by the roots must be strictly controlled (Ravet et al., 2009). The re-partition of Fe between the various parts of a plant depends both on the physiological roles that are fulfilled by the metal ion and on the physiological function of the tissues. Fe is involved as a redox-active metal in photosynthesis, mitochondrial respiration, nitrogen assimilation, hormone biosynthesis, the production and scavenging of reactive oxygen species, osmoprotection, pathogen defense, and as a limiting factor for biomass production (Briat, 2011). In the present study, an effort has been made to explore the role of seed Fe content in maintaining seed longevity of pigeonpea genotypes during storage.

\section{Materials and Methods}

Storage study was conducted at the Department of Seed Science and Technology, College of Agriculture, UAS, Raichur. The seeds of fifteen Pigeonpea genotypes viz., AGL-1919, Maruthi, TS-3R, TDRG, AGL1666, ICP-11320, GRG-140, ICP-8793, WRGE-97, AKT- 9913, BDN-2008-1, GRG13-11, GRG-2009, AGL-1603 and AGL-2249 
were stored in non woven bags for 12 months period under ambient condition. Experiment was laid out in complete randomized design in three replications. Seed samples were drawn subsequently at bimonthly intervals and tested for the following seed quality parameters.

The seed moisture content was calculated and expressed in per cent by using the standard procedure (ISTA, 2013).

Germination test was conducted with four replicates of 100 seeds each in the paper (between papers) medium in the walk-in germination room. The germination room was maintained at $25 \pm 1^{\circ} \mathrm{C}$ temperature and $90 \pm$ $5 \% \mathrm{RH}$. At the end of sixth day of placing the seeds, the number of normal seedlings in each replication was counted and the germination was calculated and expressed in percentage (ISTA, 2013). From the germination test, ten normal seedlings were randomly selected from each treatment on the day of final count. The seedling length was measured from tip of shoot to root tip and the mean length was calculated and expressed as seedling length in centimeters (ISTA, 2013).

Seedling vigour index was computed by adopting the formula as suggested by AbdulBaki and Anderson (1973) and expressed in whole number.

Seedling vigour index $=$ Germination $(\%) \times$ Mean seedling length $(\mathrm{cm})$

From the germination test, five normal seedlings were taken in butter paper and dried in hot air oven maintained at $70 \pm 2^{\circ} \mathrm{C}$ temperature for 24 hours. Then, the seedlings were removed and allowed to cool in a desiccator for 30 minutes before weighing in an electronic balance. The average weight was calculated and expressed as seedling dry weight in milligram (ISTA, 2013).
Seeds were germinated on paper medium with four replications of 100 seeds each. The number of seeds germinated was recorded daily up to the day of final count. The speed of germination was calculated by using the formula as suggested by Maguire (1962).

Seeds were germinated on paper medium with four replications of 100 seeds each. The number of seeds germinated was recorded daily up to the day of final count. The speed of germination was calculated by using the formula as suggested by Maguire (1962).

Speed of germination $=$

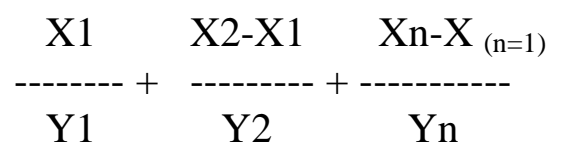

Where,

$\mathrm{Xn}=$ Number of seeds germinated at $\mathrm{n}^{\text {th }}$ count $\mathrm{Y} n=$ Number of days from sowing to $\mathrm{n}^{\text {th }}$ count

Five grams of seeds in two replications were soaked in acetone for half a minute and thoroughly washed in distilled water three times. Then, the seeds were soaked in $25 \mathrm{ml}$ distilled water and kept in an incubator maintained at $25 \pm 1{ }^{\circ} \mathrm{C}$ for twelve hours. The seed leachate was collected and the volume was made up to $25 \mathrm{ml}$ by adding distilled water. The electrical conductivity of the seed leachate was measured in the digital conductivity bridge (ELICO) with a cell constant 1.0 and the mean values were expressed in desi Simon per meter $\left(\mathrm{dSm}^{-1}\right)$ (Anon., 2013).

The 25 representative seeds from each treatment were taken and preconditioned by soaking in water overnight at room temperature. Seeds were taken at random and the embryos were excised. The embryos were 
steeped in 0.25 per cent solution of 2,3,5triphenyl tetrazolium chloride solution and kept in dark for two hours at $40{ }^{\circ} \mathrm{C}$ for staining. The stained seeds were thoroughly washed with water and then soaked in $10 \mathrm{ml}$ of 2 methoxy ethanol (methyl cellosolve) and kept overnight for extracting the red colour formazan. The intensity of red colour was measured using ELICO UV-VIS spectrophotometer (model SC-159) using blue filter $(470 \mathrm{~nm})$ and methyl cellosolve as the blank. The OD value obtained was reported as dehydrogenase activity (Kittock and Law, 1968).

The $\alpha$-amylase activity was analyzed as per the method suggested by Simpson and Naylor (1962). Two gram of agar shreds and one gram of potato starch was mixed together in water to form paste and the volume was made up to $100 \mathrm{ml}$ with distilled water. The homogenous solution of agar-starch mixture after boiling was poured into sterilized petridishes and allowed to settle in the form of gel after cooling. The pre-soaked (for 8 hour) and half cut seeds (with their half cotyledon and embryo portion intact) were placed in the petri-dishes in such a way that the cotyledon part remained in contact with agar-starch gel. The petri-dishes were closed and kept in dark at $30{ }^{\circ} \mathrm{C}$. After 48 hour, the petri-dishes were uniformly smeared with potassium iodide solution $(0.44 \mathrm{~g}$ of iodine crystal $+20.008 \mathrm{~g}$ potassium iodide in $500 \mathrm{ml}$ distilled water) and excess solution was drained off after few minutes. The diameter of halo (clear) zone formed around the seed was measured in $\mathrm{mm}$ and reported as $\alpha$-amylase activity.

Before micronutrient (iron) analysis, the seeds of all the 15 genotypes were subjected for grinding. Ground seeds (500 $\mathrm{mg})$ were digested with $6 \mathrm{~mm}$ of concentrated nitric acid $\left(70 \% \mathrm{HNO}_{3}\right)$. The samples were heated to $90^{\circ} \mathrm{C}$ for $1 \mathrm{hr}$ and then $3 \mathrm{ml}$ of $30 \%$ hydrogen peroxide $\left(\mathrm{H}_{2} \mathrm{O}_{2}\right)$ were added. When the organic matter was digested, the solution was diluted with millipore water to $25 \mathrm{ml}$ mineral concentrations were determined by inductively couple plasma-emission spectrometry (ICP-ES; ICP-6500 Duo, Thermo Fisher Scientific, Pittsburg, PA, USA), (Darshika et al., 2012).

\section{Procedure of digestion of pigeonpea seeds for Iron estimation}

From each genotype one gram of pigeonpea seed powder was taken in $100 \mathrm{ml}$ conical flask and $10 \mathrm{ml}$ of di-acid mixture $\left(\mathrm{HNO}_{3}\right.$ : $\mathrm{HClO}_{4}=2: 1$ ) added to it. It was kept overnight at room temperature (2.00 PM to $11.00 \mathrm{AM}$ ). Then the conical flask was placed on sand bath at temperature $180-200{ }^{\circ} \mathrm{C}$ for one to two hours. After a few minutes brown fume was evolved. This indicated the starting of digestion process. Finally white fume was seen by clearing the solution. At the bottom of the conical flask about 2-3 ml solution was noticed. After that, heating was stopped and the digested sample was cooled for 20 minutes. Then about 20-30 ml distilled water was added to each conical flask and the solution was filtered into a $50 \mathrm{ml}$ volumetric flask and volume was made up to the mark $(50 \mathrm{ml})$ by adding distilled water.

\section{Iron content determination by AAS}

It is based on the principle that atoms of iron $(\mathrm{Fe})$ which normally remain in ground state, under flame condition absorb energy when subjected to radiation is proportional to the specific wavelength. The absorption of radiation is proportional to the concentration of iron. Iron content was estimated in the aliquot of seed extract by using Atomic Absorption Spectrophotometer (AAS) at $248.33 \mathrm{~nm}$ and $213 \mathrm{~nm}$, respectively.

The data obtained from three experiments were statistically analyzed as per Cochran and Cox, 1967. 


\section{Results and Discussion}

During storage, quality of the seed varies among varieties, genera to genera as the viability and vigour of seeds are influenced by genetic factors of the genotypes involved (Agarwal, 1974). Apart from genetic factors, the storability of different varieties is also regulated by initial seed quality, physical and chemical composition of seed (Doijoidi, 1988). As different cultivars possess different physical structure and chemical composition which determines the longevity of seed in storage.

One of the critical factors that determine the viability of seeds in storage is seed moisture content (Harrington and Douglas, 1970). The moisture content of seeds recorded at bimonthly interval showed increasing trend during storage (except after second and twelve months of storage), irrespective of the genotypes. Significantly highest moisture content was observed in AGL-1666 (9.48\%) and lower in AGL-2249 (7.29\%) at the end of storage period (Table 1). Presence of lower moisture content during second and twelve months after storage period could be due to lower atmospheric relative humidity and higher temperature that caused loss of moisture content from the seeds. The increase in moisture could be due to hygroscopic nature of the seed enabling moisture absorption from the surrounding atmosphere. The container used in the present study was cloth bag which is moisture pervious. The other probable means of seed moisture increase are metabolic release of water, insect infestation and fungal infection as reported by Raja (2003).

Among the genotypes, AGL-2249 recorded higher seed germination initially (96.13\%) and maintained the same up to 12 months of storage (84.57\%), while genotype AGL-1666 recorded lower germination throughout the storage period (Table 1). The per cent reduction was highest in AGL- 1666 (10.19\%) and lowest in AGL-2249 (11.56\%). Even after 12 months of storage, out of fifteen genotypes, ten genotypes maintained germination percentage above the minimum seed certification standard $(75.00 \%)$. There was linear decrease in the percentage of pigeonpea seed germination during the twelve month-period storage. Moreover, explains that from the physiological maturity point, a process of seed deterioration starts in a progressive rate until the unfeasibility of the seed or embryo death. The decrease in germination percentage during storage is mainly due to age induced phenomenon in most of kind of seeds which is inevitable and irreversible and also this may be due to genotypic factors and physio-chemical properties. Similar genotypic variation for germination percentage was reported by Kumar et al., (1997) in cultivars of pea and also this variation in storability among the genotypes was obviously due to the genetic control to resist deterioration during storage (Yogalakshmi et al., 1996). Higher quality parameters observed in genotype AGL-2249 might be due to presence of high iron content which reduce the lipid peroxidation by preventing the production of reactive oxygen species (ROS) during storage (Cakmak, 2000).

The genotype AGL-2249 recorded highest speed of germination in all the months of storage (26.20 at initial and 23.29 at the end of storage) over rest of the genotypes, whereas lowest was observed in AGL-1666 (Table 2). This increased speed of germination could be ascribed to activation of cells, which results in the enhancement of mitochondrial activity leading to the formation of high energy compounds and vital biomolecules, which were made available during the early phase of germination (Dharmalingam et al., 1998) and 
nitrogen containing compound that might have stimulated speed of germination with increase in seed cytokinin content, occurring naturally in seeds which interact with growth inhibitors and enhance metabolic process and finally, leading to higher speed of germination.

Deterioration in seed quality associated with decrease in seedling length, dry matter production and vigour index with the passage of time in storage has been confirmed by Singh et al., (2004). In the present study AGL-2249 genotype proved best as it recorded highest seedling length $(27.67 \mathrm{~cm})$, seedling dry weight (80.67 $\mathrm{mg} \mathrm{g}$ ) and seedling vigour index (1303) (Table 1 and 2). This variation may be due to the inherent genotypic difference and the amount of stored food reserve mobilized as reflected in test weight which ultimately contributed to longer seedling length, higher seedling dry weight as well as vigour. Similar decrease in vigour index with advancement of storage and variation among the genotypes was reported by Kumar et al., (2007) in varieties of soybean and Singh et al., (1998) in rice bean types.

Biochemical parameters viz., total dehydrogenase enzyme activity and $\alpha$ amylase activity will be of much use if any of the genotypes possessing maximum of these characteristics with less of electrical conductivity of seed leachates for further seed quality studies vis-à-vis transferring of these parameters to the promising cultivars through conventional / molecular approaches in crop improvement programme.

In the present study, electrical conductivity of the seed leachate increased with increase in period of storage. Similar observation was also noticed by Hosamani et al., (2013) in soybean. Among the genotypes, AGL-2249 released lower electrolytes to seed leachate and genotype AGL-1666 recorded more EC by releasing more electrolytes to seed leachates (Table 3). The significant variation in EC may be due to the anatomical structure, membrane permeability and composition of seed coat. As seeds of AGL-2249 and MARUTI contained more moisture content it might have lead to more cellular membrane deterioration causing more leakage of solutes from the membrane (Paul and Ramaswamy, 1979).

Total dehydrogenase enzyme activity which exists in mitochondria and necessary for respiratory process indicates the level of seed viability and vigour (Anonymous, 2012). The total dehydrogenase enzyme activity is a good stable metabolic marker to estimate the degree of vigour in seeds (Saxena et al., 1987) and has positive association with vigour and viability of seeds (Rudrapal and Basu, 1982; Halder and Gupta, 1982). The present study revealed that, the total dehydrogenase enzyme activity was reduced with advancement of storage period. At the end of storage period AGL-2249 recorded higher TDH activity (0.551 OD value), whereas, AGL-1666 recorded lower (0.404 OD value) (Table 3). This might be due to the activity of enzyme responsible for respiration of the seed reduced with the age of the seeds. The decrease in enzyme activity was observed by Anandhi (2001) in cowpea with advances in storage period or entrance of seed in senescence phase. Decrease in dehydrogenase enzyme activity may be related to age induced deterioration which is a common phenomenon in any living entity and difference in genotypic response may be due to variation in inherent genotypic composition to withstand the impact of ageing. Present results are in agreement with the earlier findings of Harish (2014) in pigeonpea and chickpea.

The early vigour in pigeonpea is measured through root and shoot length of seedlings. 
The information on $\alpha$-amylase isozymes and their association with early vigour related traits have been reported earlier. Svetlana et al., (2013) reported that radicle extension was closely correlated with $\alpha$ - amylase activity and suggested that this might be a limiting step in germination. In the present findings, although $\alpha$-amylase activity declined in all the genotypes during storage period but, minimum loss of á- amylase activity (26.80 $\mathrm{mm}$ to $23.97 \mathrm{~mm}$ ) was noticed in AGL-1666 and highest in AGL- 2249 (32.56 mm to $28.46 \mathrm{~mm}$ ) (Table 3). Diwan and Shenoy (2001) observed the association between high mobility type amylase isozymes and higher vigour in paddy genotypes and reported that, it could be due to the presence of genes controlling both the traits on a single chromosome.

Irrespective of the genotypes, seed protein content decreased during storage. Similar results with low protein content in aged seeds were documented by Roberts (1972) and Anderson (1973). In present investigation, at the end of twelve months of storage period highest protein content was recorded in GRG$2009(21.20 \%)$ followed by MARUTI $(20.83 \%)$ while, the lowest protein content was recorded in WRGE-97 (19.43\%) (Table 4). Reduction in protein could be related to increase in moisture content that might have activated the proterolytic enzymes (Raja, 2003).

In the present study, micronutrient content (Fe) of seeds was estimated before keeping the seeds for storage and at end of storage period to know the association with seed quality parameters. Irrespective of the genotypes, slight decline in Fe content were noticed during storage.

Among the genotypes, AGL-2249 maintained higher Fe content $(85.21 \mathrm{ppm}$ at initial and $85.01 \mathrm{ppm}$ at the end of storage period) throughout the storage period (Table 4). These type of results have not been reported earlier so far and hence there is a scope for in depth study on this area in order to correlate the seed quality traits with that of micronutrient in seeds during storage there by, selection of genotypes during breeding programme can be thought off for transferring genes responsible for maintenance of micro element in seeds during storage to the promising genotypes having short seed viability.

\section{Correlation between seed quality parameters and seed Fe content}

There is evidence in literature demonstrating that role and association of $\mathrm{Fe}$ in enhancing the seed germination and vigour (Rengel 2008 and Boonchuay et al., 2013). The acquisition of metal ions, such as Fe, is important for plant survival. Iron has special importance because its ability to change redox states, making it an indispensable cofactor that is responsible for the function of electron transporter chains and catalytic processes (Briat, 2011). The re-partition of Fe between the various parts of a plant depends both on the physiological roles that are fulfilled by the metal ion and on the physiological function of the tissues (Briat, 2011).

$\mathrm{Fe}$ is involved as a redox-active metal in photosynthesis, mitochondrial respiration, nitrogen assimilation, hormone biosynthesis, the production and scavenging of reactive oxygen species, osmoprotection, pathogen defense, and as a limiting factor for biomass production plays an important role in enhancing the seed germination.

In the present study, seed iron content exhibited positive significant association with all the seed quality parameters at initial and also at the end of storage period except electrical conductivity (Table 5 and 6). 
Table.1 Seed moisture content (\%), germination (\%) and seedling length (cm) as influenced by pigeonpea genotypes during storage

\begin{tabular}{|c|c|c|c|c|c|c|c|c|c|}
\hline \multirow[b]{3}{*}{ Genotypes } & \multicolumn{9}{|c|}{ Months of storage } \\
\hline & \multicolumn{3}{|c|}{ Moisture content } & \multicolumn{3}{|c|}{ Germination } & \multicolumn{3}{|c|}{ Seedling length } \\
\hline & $\mathbf{0}$ & 6 & 12 & $\mathbf{0}$ & 6 & 12 & $\mathbf{0}$ & 6 & 12 \\
\hline$G_{1}:$ AGL-1919 & 8.71 & 9.01 & 8.65 & 85.78 & 82.33 & 77.33 & 26.53 & 24.25 & 23.22 \\
\hline $\mathbf{G}_{2}:$ MARUTI & 7.70 & 8.00 & 7.64 & 93.37 & 88.67 & 84.39 & 30.28 & 28.25 & 27.00 \\
\hline$G_{3}:$ TS-3R & 8.15 & 8.45 & 8.09 & 86.75 & 83.00 & 78.53 & 25.90 & 23.93 & 21.95 \\
\hline$G_{4}:$ TDGR-33 & 8.38 & 8.67 & 8.31 & 88.93 & 84.67 & 79.47 & 25.83 & 23.84 & 22.61 \\
\hline$G_{5}:$ AGL-1666 & 9.54 & 9.84 & 9.48 & 82.67 & 77.20 & 72.48 & 24.54 & 22.82 & 21.39 \\
\hline$G_{6}:$ ICP-11320 & 8.94 & 9.23 & 8.87 & 88.57 & 84.67 & 80.90 & 25.77 & 23.82 & 22.78 \\
\hline $\mathbf{G}_{7}:$ GRG-140 & 8.66 & 8.96 & 8.60 & 82.97 & 78.67 & 75.06 & 25.20 & 23.70 & 22.37 \\
\hline G8: ICP-8793 & 8.77 & 9.06 & 8.70 & 83.00 & 78.67 & 76.18 & 26.03 & 24.15 & 23.10 \\
\hline G9: WRGE-97 & 9.03 & 9.32 & 8.96 & 84.67 & 80.00 & 75.83 & 25.87 & 23.38 & 22.32 \\
\hline $\mathbf{G}_{10}:$ AKT-1193 & 8.07 & 8.36 & 8.00 & 92.80 & 86.67 & 81.93 & 27.30 & 25.33 & 24.17 \\
\hline$G_{11}: B D N-2008-12$ & 8.84 & 9.14 & 8.78 & 86.23 & 81.67 & 76.73 & 24.87 & 22.88 & 21.33 \\
\hline G12: GRG-13-1 $_{1}$ & 8.48 & 8.77 & 8.41 & 92.71 & 88.00 & 82.87 & 28.91 & 26.47 & 25.00 \\
\hline$G_{13}:$ GRG-2009 & 9.13 & 9.42 & 9.06 & 84.24 & 80.60 & 75.40 & 25.17 & 23.65 & 22.65 \\
\hline$G_{14}: A G L-1603$ & 8.21 & 8.51 & 8.15 & 91.76 & 86.67 & 81.41 & 26.90 & 24.50 & 23.50 \\
\hline $\mathbf{G}_{15}:$ AGL-2249 & 7.35 & 7.65 & 7.29 & 96.13 & 90.40 & 84.57 & 32.67 & 29.94 & 27.67 \\
\hline Mean & 8.53 & 8.83 & 8.47 & 87.74 & 83.46 & 78.87 & 26.78 & 24.73 & 23.40 \\
\hline S.Em \pm & 0.11 & 0.04 & 0.09 & 0.547 & 0.696 & 0.786 & 0.54 & 0.54 & 0.40 \\
\hline CD@1\% & 0.43 & 0.17 & 0.35 & 2.127 & 2.708 & 3.056 & 2.13 & 2.13 & 1.57 \\
\hline
\end{tabular}


Table.2 Seedling dry weight (mg), speed of germination and seedling vigour index as influenced by pigeonpea genotypes during storage

\begin{tabular}{|c|c|c|c|c|c|c|c|c|c|}
\hline \multirow[b]{3}{*}{ Genotypes } & \multicolumn{9}{|c|}{ Months of storage } \\
\hline & \multicolumn{3}{|c|}{ Seedling dry weight (mg) } & \multicolumn{3}{|c|}{ Speed of germination } & \multicolumn{3}{|c|}{ Seedling vigour index } \\
\hline & $\mathbf{0}$ & 6 & 12 & $\mathbf{0}$ & 6 & 12 & $\mathbf{0}$ & 6 & 12 \\
\hline$G_{1}:$ AGL-1919 & 81.07 & 79.72 & 78.00 & 23.72 & 22.63 & 21.01 & 1146 & 1096 & 1048 \\
\hline G $_{2}$ : MARUTI & 83.02 & 81.72 & 80.00 & 25.33 & 24.18 & 22.72 & 1403 & 1337 & 1299 \\
\hline$G_{3}:$ TS-3R & 81.02 & 79.71 & 77.67 & 23.57 & 22.57 & 21.10 & 1135 & 1084 & 1033 \\
\hline G4: TDGR-33 & 79.40 & 77.85 & 76.24 & 23.28 & 22.52 & 21.22 & 1148 & 1103 & 1055 \\
\hline$G_{5}:$ AGL-1666 & 78.12 & 76.33 & 75.25 & 20.79 & 20.38 & 19.48 & 1086 & 1055 & 1022 \\
\hline G6: ICP-11320 & 78.85 & 77.67 & 76.00 & 22.61 & 21.99 & 20.90 & 1140 & 1096 & 1050 \\
\hline$G_{7}:$ GRG-140 & 79.47 & 78.08 & 76.74 & 21.24 & 20.77 & 19.75 & 1111 & 1085 & 1044 \\
\hline G8: ICP-8793 & 79.30 & 77.67 & 75.87 & 21.52 & 20.74 & 19.90 & 1114 & 1075 & 1037 \\
\hline G9：WRGE-97 & 80.55 & 79.00 & 77.87 & 22.58 & 21.54 & 20.50 & 1133 & 1095 & 1045 \\
\hline$G_{10}: A K T-1193$ & 81.80 & 79.96 & 78.00 & 23.54 & 22.73 & 21.38 & 1261 & 1198 & 1115 \\
\hline$G_{11}: B D N-2008-12$ & 79.62 & 77.55 & 76.00 & 22.77 & 21.58 & 20.72 & 1092 & 1057 & 1031 \\
\hline$G_{12}:$ GRG-13-1 & 82.05 & 80.83 & 78.83 & 24.75 & 23.30 & 22.12 & 1338 & 1294 & 1193 \\
\hline$G_{13}:$ GRG-2009 & 77.90 & 76.83 & 75.20 & 21.50 & 20.75 & 19.86 & 1127 & 1083 & 1034 \\
\hline$G_{14}: A G L-1603$ & 78.74 & 76.99 & 75.00 & 23.77 & 22.30 & 21.35 & 1232 & 1187 & 1083 \\
\hline G $_{15}:$ AGL-2249 & 84.33 & 82.72 & 80.67 & 26.20 & 24.80 & 23.29 & 1560 & 1382 & 1303 \\
\hline Mean & 80.35 & 78.84 & 78.00 & 23.14 & 22.18 & 21.02 & 1202 & 1148 & 1093 \\
\hline S.Em \pm & 0.83 & 0.60 & 0.42 & 0.29 & 0.42 & 0.49 & 33.58 & 20.12 & 21.91 \\
\hline CD@1\% & 3.22 & 2.35 & 1.62 & 1.15 & 1.63 & 1.92 & 130.61 & 78.26 & 85.23 \\
\hline
\end{tabular}


Table.3 Electrical conductivity $(\mu \mathrm{S} / \mathrm{cm})$, dehydrogenase enzyme activity and $\alpha$-amylase activity (mm) as influenced by pigeonpea genotypes during storage

\begin{tabular}{|c|c|c|c|c|c|c|c|c|c|}
\hline \multirow[t]{3}{*}{ Genotypes } & \multicolumn{9}{|c|}{ Months of storage } \\
\hline & \multicolumn{3}{|c|}{ Electrical conductivity } & \multicolumn{3}{|c|}{ Dehydrogenase enzyme activity } & \multicolumn{3}{|c|}{$\alpha$-amylase activity } \\
\hline & $\mathbf{0}$ & 6 & 12 & $\mathbf{0}$ & 6 & 12 & $\mathbf{0}$ & 6 & 12 \\
\hline $\mathbf{G}_{1}:$ AGL-1919 & 0.372 & 0.516 & 1.089 & 0.816 & 0.626 & 0.458 & 28.23 & 26.42 & 24.79 \\
\hline $\mathbf{G}_{2}:$ MARUTI & 0.307 & 0.451 & 1.024 & 0.863 & 0.673 & 0.505 & 31.07 & 29.73 & 27.68 \\
\hline$G_{3}:$ TS-3R & 0.355 & 0.499 & 1.072 & 0.829 & 0.639 & 0.471 & 29.09 & 27.93 & 25.82 \\
\hline$G_{4}:$ TDGR-33 & 0.357 & 0.501 & 1.074 & 0.839 & 0.649 & 0.481 & 29.45 & 27.92 & 25.98 \\
\hline$G_{5}:$ AGL-1666 & 0.397 & 0.541 & 1.114 & 0.762 & 0.572 & 0.404 & 26.80 & 24.99 & 23.97 \\
\hline G6: ICP-11320 & 0.367 & 0.511 & 1.084 & 0.839 & 0.649 & 0.481 & 29.06 & 27.44 & 25.77 \\
\hline$G_{7}:$ GRG-140 & 0.352 & 0.496 & 1.069 & 0.794 & 0.604 & 0.436 & 27.21 & 25.86 & 24.09 \\
\hline G8: ICP-8793 & 0.362 & 0.506 & 1.079 & 0.806 & 0.616 & 0.448 & 27.29 & 25.92 & 24.79 \\
\hline G9：WRGE-97 & 0.352 & 0.496 & 1.069 & 0.809 & 0.619 & 0.451 & 27.84 & 26.39 & 24.82 \\
\hline$G_{10}: A K T-1193$ & 0.373 & 0.517 & 1.090 & 0.850 & 0.660 & 0.492 & 29.74 & 28.26 & 25.97 \\
\hline$G_{11}: B D N-2008-12$ & 0.355 & 0.499 & 1.072 & 0.830 & 0.640 & 0.472 & 29.03 & 27.45 & 24.82 \\
\hline G $_{12}:$ GRG-13-1 & 0.375 & 0.519 & 1.092 & 0.843 & 0.653 & 0.485 & 30.45 & 28.82 & 26.60 \\
\hline G13: GRG-2009 & 0.359 & 0.503 & 1.076 & 0.814 & 0.624 & 0.456 & 29.02 & 28.04 & 25.94 \\
\hline$G_{14}: A G L-1603$ & 0.384 & 0.528 & 1.101 & 0.851 & 0.661 & 0.493 & 29.70 & 27.96 & 25.91 \\
\hline$G_{15}: A G L-2249$ & 0.287 & 0.431 & 1.004 & 0.909 & 0.719 & 0.551 & 32.56 & 30.93 & 28.46 \\
\hline Mean & 0.357 & 0.500 & 1.074 & 0.830 & 0.640 & 0.472 & 29.10 & 27.60 & 25.69 \\
\hline S.Em \pm & 0.004 & 0.006 & 0.012 & 0.002 & 0.002 & 0.006 & 0.23 & 0.32 & 0.30 \\
\hline CD@1\% & 0.015 & 0.0250 & 0.047 & 0.008 & 0.008 & 0.025 & 0.92 & 1.27 & 1.18 \\
\hline
\end{tabular}


Table.4 Protein content $(\%)$ and seed iron content $(\mathrm{ppm})$ as influenced by pigeonpea genotypes during storage

\begin{tabular}{|c|c|c|c|c|}
\hline \multirow{3}{*}{ Genotypes } & \multicolumn{4}{|c|}{ Months of storage } \\
\hline & \multicolumn{2}{|c|}{ Protein content } & \multicolumn{2}{|c|}{ Iron content } \\
\hline & $\mathbf{0}$ & 12 & $\mathbf{0}$ & 12 \\
\hline G $_{1}:$ AGL-1919 & 21.12 & 19.90 & 63.84 & 63.63 \\
\hline $\mathbf{G}_{2}:$ MARUTI & 22.63 & 20.83 & 65.99 & 65.83 \\
\hline$G_{3}:$ TS-3R & 21.32 & 20.34 & 60.26 & 60.05 \\
\hline G $_{4}$ : TDGR-33 & 20.85 & 19.66 & 26.85 & 26.65 \\
\hline$G_{5}:$ AGL-1666 & 20.81 & 19.58 & 70.47 & 70.28 \\
\hline$G_{6}:$ ICP-11320 & 21.35 & 20.16 & 88.68 & 88.45 \\
\hline$G_{7}:$ GRG-140 & 21.93 & 20.49 & 60.09 & 59.88 \\
\hline G8: ICP-8793 & 21.59 & 20.29 & 47.9 & 47.69 \\
\hline G9：WRGE-97 & 20.64 & 19.43 & 43.88 & 43.64 \\
\hline $\mathbf{G}_{10}:$ AKT-1193 & 21.47 & 20.45 & 70.83 & 70.64 \\
\hline $\mathrm{G}_{11}: \mathrm{BDN}-2008-12$ & 22.25 & 20.85 & 65.70 & 65.49 \\
\hline $\mathbf{G}_{12}:$ GRG-13-1 & 21.99 & 20.78 & 74.6 & 74.38 \\
\hline G $_{13}:$ GRG-2009 & 22.50 & 21.20 & 79.85 & 79.64 \\
\hline$G_{14}: A G L-1603$ & 21.32 & 20.47 & 73.77 & 73.56 \\
\hline G $_{15}:$ AGL-2249 & 21.59 & 20.45 & 85.21 & 85.01 \\
\hline Mean & 21.56 & 20.33 & 65.19 & 64.99 \\
\hline S.Em \pm & 0.10 & 0.407 & 0.19 & 0.22 \\
\hline CD@1\% & 0.42 & NS & 0.75 & 0.85 \\
\hline
\end{tabular}


Table.5 Correlation between micronutrient $(\mathrm{Fe})$ content and seed quality parameters at initial month of storage

\begin{tabular}{|c|c|c|c|c|c|c|c|c|c|c|}
\hline Parameters & $\mathbf{X}_{1}$ & $\mathbf{X}_{2}$ & $\mathbf{X}_{3}$ & $\mathbf{X}_{4}$ & $\mathbf{X}_{5}$ & $\mathbf{X}_{6}$ & $\mathbf{X}_{7}$ & $\mathbf{X}_{8}$ & $\mathbf{X}_{9}$ & $\mathbf{X}_{10}$ \\
\hline $\mathrm{X}_{1}$ & 1 & & & & & & & & & \\
\hline $\mathbf{X}_{2}$ & $0.847 * *$ & 1 & & & & & & & & \\
\hline $\mathbf{X}_{3}$ & $0.728 * *$ & $0.880 * *$ & 1 & & & & & & & \\
\hline $\mathbf{X}_{4}$ & $0.906 * *$ & $0.888 * *$ & $0.865^{* *}$ & 1 & & & & & & \\
\hline $\mathbf{X}_{5}$ & $0.885^{* *}$ & $0.988 * *$ & $0.844 * *$ & $0.874 * *$ & 1 & & & & & \\
\hline $\mathbf{X}_{6}$ & -0.461 & $-0.727 * *$ & $-0.693 * *$ & $-0.591 *$ & $-0.690 * *$ & 1 & & & & \\
\hline $\mathbf{X}_{\mathbf{7}}$ & $0.902 * *$ & $0.827 * *$ & $0.723 * *$ & $0.895 * *$ & $0.830 * *$ & $-0.660 * *$ & 1 & & & \\
\hline $\mathbf{X}_{8}$ & $0.934 * *$ & $0.862 * *$ & $0.729 * *$ & $0.910 * *$ & $0.893 * *$ & $-0.627 *$ & $.937 * *$ & 1 & & \\
\hline $\mathbf{X}_{9}$ & 0.202 & 0.268 & 0.179 & 0.179 & 0.289 & -0.367 & 0.223 & 0.365 & 1 & \\
\hline $\mathbf{X}_{10}$ & 0.359 & 0.329 & 0.141 & 0.224 & 0.387 & -0.054 & 0.283 & 0.384 & 0.398 & 1 \\
\hline \multicolumn{11}{|c|}{$\begin{array}{l}* \text { Correlation is significant at } 0.01 \text { level (2-tailed) } \\
* \text {. Correlation is significant at } 0.05 \text { level (2-tailed) }\end{array}$} \\
\hline $\begin{array}{l}\mathrm{X}_{1}: \text { Germination }(\%) \\
\mathrm{X}_{5}: \text { Seedling vigour index } \\
\mathrm{X}_{9}: \text { Protein content }(\%)\end{array}$ & $\begin{array}{r}\mathrm{X}_{2}: \mathrm{s} \\
\mathrm{X}_{6}: \text { Elect } 1 \\
\mathrm{X}_{10}: \text { Iron } \mathrm{c}\end{array}$ & $\begin{array}{l}\text { edling length } \\
\text { cal conductiv } \\
\text { ntent(ppm) }\end{array}$ & $\begin{array}{l}(\mathrm{cm}) \\
\mathrm{ty}(\mathrm{dS} / \mathrm{cm})\end{array}$ & $\begin{array}{r}\mathrm{X}_{3}: \text { Seedlil } \\
\mathrm{X}_{7} \text { : Total deh }\end{array}$ & $\begin{array}{l}\text { dry weight } \\
\text { drogenase en }\end{array}$ & $\begin{array}{l}\text { ng) } \\
\text { yme activity }\end{array}$ & $\begin{array}{r}\mathrm{X}_{4}: \text { Spee } \\
\mathrm{X}_{8}: \alpha-\mathrm{Am}\end{array}$ & $\begin{array}{l}\text { f germina } \\
\text { se activity }\end{array}$ & $\mathrm{n}(\mathrm{mm})$ & \\
\hline
\end{tabular}


Table.6 Correlation between micronutrient $(\mathrm{Fe})$ content and seed quality parameters at 12 month of storage

\begin{tabular}{|c|c|c|c|c|c|c|c|c|c|c|}
\hline Parameters & $\mathbf{X}_{1}$ & $\mathbf{X}_{2}$ & $\mathbf{X}_{3}$ & $\mathbf{X}_{4}$ & $\mathbf{X}_{5}$ & $\mathbf{X}_{6}$ & $\mathbf{X}_{7}$ & $\mathbf{X}_{8}$ & $X_{9}$ & $\mathbf{X}_{10}$ \\
\hline $\mathrm{X}_{1}$ & 1 & & & & & & & & & \\
\hline $\mathbf{X}_{2}$ & $0.833 * *$ & 1 & & & & & & & & \\
\hline $\mathbf{X}_{3}$ & $0.659 * *$ & $0.802 * *$ & 1 & & & & & & & \\
\hline $\mathbf{X}_{4}$ & $0.937 * *$ & $0.864 * *$ & $0.804 * *$ & 1 & & & & & & \\
\hline$X_{5}$ & $0.822 * *$ & $0.968 * *$ & $0.828 * *$ & $0.888 * *$ & 1 & & & & & \\
\hline $\mathbf{X}_{6}$ & $-0.536^{*}$ & $-0.714 * *$ & $-0.727 * *$ & $-0.673 * *$ & $-0.746 * *$ & 1 & & & & \\
\hline $\mathbf{X}_{7}$ & $0.927 * *$ & $0.824 * *$ & $0.662 * *$ & $0.925 * *$ & $0.800 * *$ & $-0.705 * *$ & 1 & & & \\
\hline $\mathbf{X}_{8}$ & $0.888 * *$ & $0.877 * *$ & $0.681 * *$ & $0.906 * *$ & $0.874 * *$ & $-0.723 * *$ & $0.925 * *$ & 1 & & \\
\hline $\mathbf{X}_{9}$ & 0.336 & 0.335 & 0.106 & 0.247 & 0.346 & -0.246 & 0.406 & 0.411 & 1 & \\
\hline $\mathbf{X}_{10}$ & 0.322 & 0.338 & 0.123 & 0.256 & 0.332 & -0.077 & 0.310 & 0.346 & $0.517 *$ & 1 \\
\hline
\end{tabular}

**. Correlation is significant at 0.01 level (2-tailed)

*. Correlation is significant at 0.05 level (2-tailed)

$\mathrm{X}_{1}$ : Germination $(\%) \quad \mathrm{X}_{2}$ : Seedling length $(\mathrm{cm})$

$\mathrm{X}_{3}$ : Seedling dry weight $(\mathrm{mg})$

$\mathrm{X}_{4}$ : Speed of germination $(\mathrm{mm})$

$\mathrm{X}_{5}$ : Seedling vigour index $\quad \mathrm{X}_{6}$ : Electrical conductivity $(\mathrm{dS} / \mathrm{cm}) \quad \mathrm{X}_{7}$ : Total dehydrogenase enzyme activity $\quad \mathrm{X}_{8}$ : $\alpha$ - Amylase activity

$\mathrm{X}_{9}$ : Protein content $(\%) \quad \mathrm{X}_{10}$ : Iron content $(\mathrm{ppm})$ 
Significant positive association between seedFe content and quality parameters during the storage might be due to production of reactive oxygen species (ROS) which is unavoidable and seeds /seedlings have defense mechanisms against ROS production (Qin and Liu, 2010). One of the defense enzymes against ROS is superoxide dismutase which is Zn dependent (Cakmak 2000 and Broadley et al., 2007). These findings are similar to previous results reported by Yilmaz et al., (1998) in wheat; Cakmak (2008) and Boonchuay et al., (2013) in paddy; they showed that plants emerging from seeds with high $\mathrm{Zn}$ have high seedling vigour and good field establishment.

In conclusion, a comprehensive assessment of the quality parameters revealed the critical role of seed-Fe content in regulating the metabolic processes associated with seed storability. The genotype with highest seed-Fe content (85.01 ppm) proved as good storer by recording highest seed quality parameters viz., seed germination, seedling length, seedling vigour index, seedling dry weight, speed of germination, dehydrogenase enzyme activity, $\alpha$-amylase activity with lowest electrical conductivity and moisture content at the end of twelve months of storage period. Whereas, genotypes with low seed-Fe content exhibited lowermost seed quality parameters. Therefore, it is necessary that while breeding pigeonpea varieties for better seed storability, screening for high Fe content would serve as more effective criteria, as compared to low $\mathrm{Fe}$ content.

\section{References}

Abdul-Baki, A. A and Anderson, J. D. (1973). Vigour determination by multiple criteria. Crop Sci. 13: 630-633.

Agarwal, P.K. (1974) Storage studies on maize seeds. B. Grain Tech., 12: 109112.
Anandhi, R. (2001) Seed technological studies in cowpea (Vigna unguiculata (L) Walp cv. CO-5. M.Sc.(Agri.) Thesis, Tamil Nadu Agricultural University, Coimbatore.

Anderson, J. D. (1973) Metabolic changes associated with seed senescence. Seed Sci. and Technol. 1: 401-416.

Anonymous, (2004) Morphological, chemical and electrophoretic descriptors for pigeonpea varieties/ hybrids by National Seed Project (Crops), Indian Agricultural Research Institute, New Delhi . Technical bulletin, pp 24.

Anonymous, (2012) Ministry of Agriculture, Govt. of India, www.indiastat.com

Boonchuay, P., Cakmak, K., Rerkasem, B., Chanakan and Prom-U-Thai. (2013) Effect of different foliar zinc application at different growth stages on seed zinc concentration and its impact on seedling vigor in rice. Soil Sci and $\mathrm{Pl}$ Nut. 59:180-188.

Bray, T. M and W. J. Bettger. (1990) The physiological role of zinc as an antioxidant. Free Radicals in Biology and Medicine. 8: 281-291.

Briat, J.F. 2011. Iron Nutrition and Implications for Biomass Production and the Nutritional Quality of Plant Products. The Molecular and Physiological Basis of Nutrient Use Efficiency in Crops. Wiley-Blackwell, pp. 311-334.

Broadley, M., White, P., Hammond, J., Zelko, I and A Lux. (2007) Zinc in plants. New Phytol. 173: 677-702.

Cakmak, I. (2000) Role of zinc in protecting plant cells from reactive oxygen species. New Phytol. 146: 185-205.

Cakmak., I. (2008) Enrichment of cereal grains with zinc: Agronomic or genetic biofortification. J. Plant and Soil.,302: 1-17.

Darshika, A., Thavarajah, D., McPhee, K. and Thavarajah, P. (2012) Iron, zinc, and 
magnesium rich field peas (Pisum sativum L.) with naturally low phytic acid: A potential food-based solution to global micronutrient malnutrition, $J$. Food Compo. Analy., 27:8-13.

Dharmalingam, C., Paramasivam and Sivasubramanian, V. (1998) Seed hardening to overcome adversity. The Hindu, 16, March. pp. 3.

Doijodi, S. D. (1988) Comparison of storage containers for storage of French bean seeds under ambient conditions. Seed res. 16:245-247.

Halder, S and K Gupta, K. (1982) On the mechanism of sunflower seed deterioration under low and high relative humidity. Seed Sci. \& Technol. 10: 267-270.

Harish, K.K. (2014) Studies on seed priming in pigeonpea and chickpea. $M . S c$ (Agri.) Thesis. Uni. of Agri. Sci., Raichur. Karnataka.

Harrington, J. F and J. E Douglass. (1970) Seed storage and packing application for India. Published by National Seeds Corporation Ltd., New Delhi.

Hosamani, J., Dadlani, M., Santha I. M., Arun Kumar M. B. and Jacob, S. R.(2013) Biochemical phenotyping of soybean [Glycine $\max$ (L.) Merill] genotypes to establish the role of lipid peroxidation and antioxidant enzymes in seed longevity. Agric. Res., 2(2):119-126.

ISTA. (2013) International rules for seed testing. Seed Sci. \& Technol. 24(Supplement): 23-46.

Kumar, A., Kanti, K., Dadlani, M., Lal, S. K. and Vinodkumar, (2007) Screening of soybean germplasm for better storability. Seed Res., 35(1): 70-76.

Kumar, S., Singal, N. C. and Prakash, S.(1997) Inter varietal variability for seed longevity in pea (Pisum sativum). Indian Journal of Genetics and Plant breeding, 57:204-209.

Maguire, J. D. (1962) Speeds of germination- aid selection and evaluation for seedling emergence and vigor. Crop Science. 2: 176-177.

Marquez-Quiroz1, C., De-la-Cruz-Lazaro, E., Osorio-Osorio, R., and SanchezChavez, E., (2015) Biofortification of cowpea beans with iron: iron's influence on mineral content and yield. Journal of Soil Science and Plant Nutrition, 15(4): 839-847.

Paul, S. R. and Ramasamy, K. R.(1979) Relationship between seed size and seed quality attributes in cowpea. Seed Res., 7: 63-70.

Raja, K. (2003) Investigations on nursery and main field management techniques for quality seed production of rice hybrid CORH 2. Ph.D. Thesis, Tamil Nadu Agric. Univ., Coimbatore (India).

Rengel, Z. (2008) Genetic control of root exudation. Plant Soil.245: 59-70.

Roberts, E. H. (1972) Loss of viability and crop yields. In: Viability of seeds (Ed. E.H. Roberts), Chapman Hall Ltd., London, p. 313.

Rudrapal, A. B and Basu. R. N. (1982) Lipid peroxidation and membrane damage in deteriorating wheat and mustard seeds. Indian J. Expt. Biol. 20: 465-470.

Saxena, O. P., Singh, G., Pakeeraiah, T and Pandey. N.(1987) Seed deterioration studies in some vegetable seeds. Acta. Hort. 215: 39-44.

Simpson, G. M and Naylor. J. M. (1962) Dormancy studies in seeds of Avenafatua. A relationship between maltase, amylases and gibberellins. Canadian J. Bot. 40: 1659-1673.

Singh, P., Maurya, C. L., Gaura, K. K. and Bajpai, V. P. (2004) Effect of biological and chemical fungicides on longevity of rice hybrid (DRRH-1) and its parental lines seeds. 27 $7^{\text {th }}$ ISTA Congress Seed Symposium, Budapest, Hungary, pp-7076.

Singh, S. N., Singh, B. B. and Chowdry, N. 
K.(1998) Storability of rice bean seeds. Seed Tech News., 29: 36-37.

Svetlana, B., Tubic, M. and Tatic, (2013) Seed ageing in field and vegetable crops. J. Field and Veg. Crops, 30:8797.

Yilmaz A, Ekiz H, Torun B, Gultekin I, Karanlik S, Bagci S. A. and Cakmak I.(1998) Effect of different zinc application methods on grain yield and zinc concentration in wheat grown on zinc-deficient calcareous soils in Central Anatolia. J. Plant Nutr.,20: 461-471.

Yogalakshmi, J., Ponnuswamy, A. S. and Karivaratharaju, T. V. (1996) Seed storage potential of rice hybrid (CORH1) and parental lines, Madras Agri. J., 83: 729-732.

\section{How to cite this article:}

Hanumanthappa, D., S. N. Vasudevan, N. M. Shakuntala, N. M. Muniswamy, Sangeetha I. Maacha and Umesh Hiremath. 2020. Role of Seed-Fe Content on Seed Longevity of Pigeonpea Genotypes. Int.J.Curr.Microbiol.App.Sci. 9(04): 2664-2679.

doi: https://doi.org/10.20546/ijcmas.2020.904.318 